\title{
Change in approach to employee development in organizations on a regional scale
}

\author{
Zdenko Stacho \\ Institute of Civil Society, \\ University of Ss. Cyril and Methodius, \\ Slovakia \\ zdenko.stacho@ucm.sk \\ Katarína Stachová \\ Institute of Civil Society, \\ University of Ss. Cyril and Methodius, \\ Slovakia \\ katarina.stachova@ucm.sk \\ Agota Giedrè Raišienè \\ Institute of Leadership and Strategic Management, \\ Mykolas Romeris University, \\ Lithuania \\ agotar@mruni.eu
}

Abstract. Human capital is frequently viewed as the only resource that can be constantly developed, and it can be denoted as key in the long term in efforts to increase the level of organisations. This paper aims at analysing the present state of focus of Slovak organisations on systematic education, on comprehensive targeting of education on all employees, as well as on the assessment of effectiveness in education in the context of a relationship to the region in which such organisations operate. Several partial objectives, such as a questionnaire survey conducted in Slovak organisations between 2013 - 2017, were fulfilled in order to accomplish this objective. Statistical hypothesis testing aimed at specifying the relationship between the region of operation of the given organisation and the execution of activities related to systematic education of employees in it, the focus of the organisation on education of all employees, and the assessment of effectiveness in the education provided by them, confirmed a link between the analysed variables. Positive changes in the selected attributes in time were evaluated by the fixed-base index.

Keywords: employee development, human resource management, organizational learning, sustained education, regional development. 
JEL Classification: E24, J24, M12

\section{INTRODUCTION}

Contemporary society needs to invest more and more into life-long learning because of rapid changes in life and business environment. As Furnham (2009) noticed, in today's world, progress of science and technology caused virtual reality and job automation, economic shocks lead to crises in the stock markets, and current social trends are associated with demographic trends and attitudes towards relationship and materialism - all these and other challenging circumstances lead to persistent economic competition for new and different sources. On the other hand, life-long learning becomes compulsory because of so called half-life of knowledge, i.e. the time in which much of usable knowledge is reduced and shortened enormously (Jankelova et al., 2017; Korsakienè et al., 2017). Life-long learning is therefore becoming an inseparable part of the life of both employees and organisations (Vázquez et al., 2013; Hitka et al., 2017, Jankelová et al 2017) as the ability to learn quicker than competitors is the only really effective competitive advantage in the modern world (Aggestam, 2006). Any organization that learns too slow, while other organizations evaluate and overcome challenges quicker, eventually fails.

The fact that employee improvement and creation of learning organization is an important long-term business development factor allowing to maintain competitive advantage is shown by a plethora of studies in different countries and fields, e. g. Susanty \& Salwa (2017), Farrukh \& Waheed (2015), Argote \& MironSpektor (2011); Amitabh \& Sinha (2012), Lyly (2012), Vitkiene (2013), Vveinhardt \& Minkutè-Henrickson (2015), Welo \& Ringen (2018), Iqbal et al. (2018), Antonacopoulou et al. (2019), Qi \& Chau (2018). On a more narrow, organizational management level, employee improvement is especially important in order to reach organizational goals (Davar \& Parti, 2013; Farrukh \& Waheed, 2015; Mills et al., 2009). As Bilan et al. (2019) notes, the lack of workers' education is a negative factor to run business.

In order to reflect on the modern world challenges and put life-long learning to practice, understanding the importance of a learning organization on business success is not enough. As Welo and Ringen $(2018,150)$ emphasize, "any successful improvement effort has to start with measurements of key characteristics associated with current practices, followed by a contextual implementation strategy scalable to the actual business environment". Unfortunately, it should be noted that few studies examine how organizations take care of their employee improvement through education and training on a wider than sectoral scale. Since the success of separate organizations is important for the competitiveness of regions and the whole country (Susante \& Salva, 2017; Melnikas, 2014; Gavrea et al., 2011), we base our research relevance on this lack of research. Thus, the aim of the paper is to analyse the present state of focus of Slovak organisations on employees' education as well as to assess the effectiveness in education in the context of the region in which such organizations operate.

The article is arranged as follows: the theoretical analysis part describes arguments which substantiate the importance of employee improvement for organizational goals and competitiveness; methodological part raises the questions of the research and presents the construct of the research; further, the results of the research are discussed while the last part of the article formulates conclusions.

\section{LITERATURE REVIEW}

Scientific publications develop a discussion on the terms which describe employee education and training. Various terms are used and collated, the most often used of which are organizational learning, employee education, employee training, and staff development. Authors (such as Örtenblad, 2018, 2001; 
Wang \& Ahmed, 2003; Pedler \& Burgoyne, 2017) claim that it is purposeful to combine some conceptions, e. g. knowledge management and learning organization as well as to understand that the idea of a learning organization was not exhausted, it transformed. It has become more important not to discuss what a learning organization is or what is employee development or knowledge management, but to try to apply the scientists' recommendations, seek to make use of researchers' insights for the organizations' advance and sustainability. Based on this approach, we use the terms describing employee improvement interchangeably. The theoretical part attempts to substantiate why organizations should care about employee improvement while the empirical research discussion justifies why the society should care about organizations' attention to employee improvement.

Human capital is frequently viewed as the only resource that can be denoted as a key in the long term in efforts to increase the level of organisations (Chidambaram, 2014; Kruss et al., 2015, McDonell et al., 2014). The employees who are educated and whose development is paid attention by their organisations are typically highly committed in work for their organisations and in the fulfilment of organisational goals, they are proactive and constantly willing to learn (Li et al., 2009, Vnoučková, 2013, Arvanitis et al., 2015, Koisova et al., 2017). The role of managers is to identify employee potential, and create room for their development, which is essential not only for the advancement of organisations, but also for employee satisfaction (Rothwell \& Williams, 2010) as the employees often decide whether to remain in their organisation or to leave on a basis of provided development possibilities (Nilson \& Elstrom, 2012).

In order to retain the greatest possible amount of potential employees willing to learn and develop, it is desirable that organisations had developed a training system, which typically deals with the employees with key competences for the operation of the company and their successors, as well as an established programmes of education and career management for all employees who are expected to remain in the organisation for more than five years. In such case of career management, it is possible to achieve a number of positively motivated employees of up to 70 percent in only three years (Hroník, 2007).

Lyly $(2012$, 2014) states that the realization of learning organization concept became meaningful when business companies invoked employee education and training in order to increase growth, competitiveness and resilience to external changes. The creation of a learning organization became a key factor of long-term business development which helps to acquire and maintain competitive advantage (Argote \& Miron-Spektor, 2011; Susanty \& Salwa (2017), Amitabh \& Sinha, 2012; Farrukh \& Waheed, 2015) while requiring constant flexibility, openness and change acceptance (Bersènaite \& Šaparnis, 2007).

The importance of employee improvement is shown by research on the reasons of organizational failure. Having analysed a range of organizations that went bankrupt, Kyndt et. al (2013) noticed that organizations which employ lower qualification employees tend to go bankrupt more often. Davar and Parti (2013) also claim that organizational learning helps an enterprise to sustain.

It is important to emphasize that in the aspect of business competitiveness and work effectiveness, only the improvement of the whole organization is effective rather than one-time solutions (Blodgood \& Salisbury, 2001; Welo \& Ringen, 2018). For example, a research conducted by Skrickienè et al. (2018) evaluated the education and training on an organizational level as the most effective, group and team level education as less effective and individual education as least effective. Unfortunately, the research indicated that employees educated and developed themselves primarily based on their own decision, as their organisations often did not provide them with sufficient motivations and stimuli (Schlechter et al., 2014; Hoole \& Hotz, 2016; Tansley et al., 2016). Of course, employees are responsible for their improvement as well, however, employee education and training should firstly be a part of organization's strategic development (Vveinhardt \& Minkutè-Henrickson, 2015), consolidated in the organization's values, plans and daily operations (Beirat et al., 2018). 
In general, the majority of scientific studies prove that employee training is not only a matter of employees and their direct managers but a strategic task of an organization. For example, Iqbal et al. (2018) raises the attention to employee skills and abilities to the level of organizational culture and claims that high work performance culture can be created through employee education and training. Lyles (2014), Wang \& Ahmed (2003) and Brix (2019) discovered that organizational learning is related to the organization's ability to create innovations which directly decides the organization's competitiveness. Iqbal et al. (2018) also emphasizes that employee training is a systematic process dedicated to change the employee behaviour with the goal to improve organizational results. In addition, Beirat et al. (2018) states that sustained education of employees in an organization creates the spirit of interaction and knowledge sharing which directly influences the achievement of organizational goals.

The fact that employee development influences successful transformation of organization and high achievements is proved by many studies by various authors, e. g. Marquardt (1995); Marshik and Watkins (2003), Vitkienè (2013). Therefore, educating employees and implementing employee teaching/learning and improvement systems is extremely important. Nevertheless, organisations do not always respect this necessity. They implement different approaches to the educational policies and strategies, and some of them are random or unplanned, i.e. when necessary trainings are provided not sooner than after the need to gain the given knowledge or experience has arisen (Joniaková et al., 2016, Bartakova et al., 2017). Therefore, it is important to educate not only the employees of the organization but leaders as well so that they more deeply understand the importance of employee improvement.

\section{METHODOLOGY}

Different partial objectives were accomplished in order to achieve the objective of the article, such as a questionnaire survey, statistical evaluation of the formulated hypotheses, and evaluation of the overall change of the analysed attributes using the fixed-base index.

Three research questions were formulated and conditioned with regard to the objective of the article:

1. What was the score achieved by the examined organisations in their activities related to the implementation of a systematic employee education process? Are there statistically significant differences between the regions of operation of the organisations?

2. What was the score achieved by the examined organisations in the area of education of all employees? Are there statistically significant differences between the regions of operation of the organisations?

3. What was the score achieved by the examined organisations in their activities related to the assessment of effectiveness in education? Are there statistically significant differences between the regions of operation of the organisations?

The hypotheses were formulated on the basis of the defined research questions and tested in the questionnaire survey and subsequent statistical evaluation:

- Hypothesis H1: There is a statistically significant relation between the region of operation of organisations and the implementation of a systematic employee education process;

- Hypothesis H2: There is a statistically significant relation between the region of operation of organisations and focus of the organisations on education of all categories of employees;

- Hypothesis H3: There is a statistically significant relation between the region of operation of organisations and the implementation of the assessment of effectiveness in employee education.

For the needs of this article, data obtained from research conducted between 2013-2017 were applied, and the top representatives of Slovak institutions were interviewed. Its objective was to uncover 
the present state of talent management in Slovak organisations. A questionnaire in which the participants in the study responded to 90 questions focused on the issue of formal human resource management in the organisation was used as a research tool. The answers to the questions focused on employee education were used for the needs of this article. The answers to the questions focused on innovative company's environment were used for the needs of this article. The amount of the interviewed institutions was 573609 every year (depending on the availability of personal contacts of external students, which were used to address the participants in the research), while the response rate of comprehensively completed questionnaires was $60-67 \%$.

In order to define a sufficient research sample, two stratification criteria were determined. The first criterion was the region of operation of the organisation based on the NUTS classification (La Nomenclature des Unités Territoriales Statistiques - Nomenclature of territorial units for statistics created by the Statistical Office of the European Union.); Slovakia was divided according to the NUTS 2 category, while the structure of the research sample was based on the data provided by the Statistical Office of the Slovak Republic.

The second stratification criterion was a minimum number of employees, determined to 50 employees, thus excluding small enterprises from the research sample on the one hand, however the importance of focusing on a formal human resource management system in the organisations with 50 and more employees was followed on the other hand.

The data provided by the Statistical Office of the Slovak Republic during the monitored period indicated that the number of organisations with 50 and more employees in individual regions was oscillating around similar values, while the regional structure of the organisations with over 50 employees in the given years is provided in the following Table 1.

Table 1

Regional structure of organisations with more than 50 employees

\begin{tabular}{|l|c|c|c|c|}
\hline Region - NUTS II. & $\begin{array}{c}\text { Bratislava } \\
\text { Region }\end{array}$ & $\begin{array}{c}\text { Western } \\
\text { Slovakia }\end{array}$ & Central Slovakia & Eastern Slovakia \\
\hline Districts & BA & TT, TN, NR & BB, ZA & KE, PO \\
\hline Number of organisations 2013 & 1.102 & 911 & 645 & 606 \\
\hline Number of organisations 2014 & 1.098 & 904 & 644 & 612 \\
\hline Number of organisations 2015 & 1105 & 916 & 651 & 613 \\
\hline Number of organisations 2016 & 1.114 & 923 & 649 & 621 \\
\hline Number of organisations 2017 & 1.123 & 926 & 654 & 623 \\
\hline
\end{tabular}

Source: data processed according to the Statistical Office of the Slovak Republic; Authors' calculations

Determining an optimal research sample of the given basic group of organisations, Confidence Level of the research was set at $95 \%$, and Confidence Interval of the research was set at $\mathrm{H}=+/-0.10$. On the grounds of the given criteria an additional, respectively relevant research sample for individual regions of Slovakia was set in the analysed years (Table 2).

Table 2

Size of the research sample for individual regions of Slovakia

\begin{tabular}{|l|c|c|c|c|}
\hline Region - NUTS II. & $\begin{array}{c}\text { Bratislava } \\
\text { Region }\end{array}$ & $\begin{array}{c}\text { Western } \\
\text { Slovakia }\end{array}$ & Central Slovakia & $\begin{array}{c}\text { Eastern } \\
\text { Slovakia }\end{array}$ \\
\hline Districts & BA & TT, TN, NR & BB, ZA & KE, PO \\
\hline Number of organisations & $9781102-1123$ & $904-926$ & $644-654$ & $606-623$ \\
\hline Size of research sample & 88 & 87 & 84 & 83 \\
\hline
\end{tabular}

Source: own research. 
The measured values were statistically processed and assessed by calculated chain indices (values changed since the previous year), and fixed-base indices (values changed since the first year).

\section{EMPIRICAL RESULTS AND DISCUSSION}

Adaptation to global changes presupposes facing new challenges, gaining new knowledge and skills and accepting new roles and responsibilities by both employees and employers. The key role will be predominantly played by personal development, which will be responsible for an ability of employees to succeed in these challenges. With that in mind, we were interested in whether the interviewed organisations realised the need to focus on a comprehensive and systematic approach to employee education, and whether they were actually dealing with it in practice (Table 3).

Table 3

Chain index of the companies focusing on talent management

\begin{tabular}{|c|c|c|c|c|c|c|c|c|c|}
\hline \multirow{3}{*}{$\begin{array}{l}\text { Focus of organisations on } \\
\text { talent management }\end{array}$} & \multicolumn{9}{|c|}{ Share of organisations } \\
\hline & 2013 & $.14 / 12$ & 2014 & .15 & 2015 & $\cdot 1$ & 2016 & $.17 / 1 /$ & 2017 \\
\hline & $\mathbf{n}$ & C114/ 10 & $\mathbf{n}$ & C115/ 14 & $\mathbf{n}$ & C110/ 15 & $\mathrm{n}$ & C11T/10 & $\mathbf{n}$ \\
\hline $\begin{array}{l}\text { Organisations educate } \\
\text { employees systematically }\end{array}$ & 98 & 1.020 & 100 & 0.980 & 98 & 1041 & 102 & 1.059 & 108 \\
\hline $\begin{array}{l}\text { The organisation is focused on } \\
\text { education of all the categories } \\
\text { of employees }\end{array}$ & 173 & 1.006 & 174 & 1.023 & 178 & 1.051 & 187 & 1.059 & 198 \\
\hline $\begin{array}{l}\text { Organisations assess } \\
\text { effectiveness in education }\end{array}$ & 84 & 1.012 & 85 & 1.047 & 89 & 1.101 & 98 & 1.010 & 99 \\
\hline$\Sigma$ & 355 & 1.011 & 359 & 0.992 & 356 & 1.087 & 387 & 1.047 & 405 \\
\hline
\end{tabular}

Source: own research

As the comparison of the outcomes of individual years shows, a slight increase was recorded in all years with the exception of 2015, when a slight decrease in the monitored attributes of the focus of organisations on education of employees was recorded.

With regard to the aforementioned, we consider the evaluation of the overall change in the analysed attributes in the monitored period to be necessary. Table 4 presents the data processed within the performed analysis.

Table 4

Fixed-base index of the companies focusing on talent management

\begin{tabular}{|c|c|c|c|c|c|c|c|c|c|}
\hline \multirow{3}{*}{$\begin{array}{l}\text { Focus of organisations on talent } \\
\text { management }\end{array}$} & \multicolumn{9}{|c|}{ Share of organisations } \\
\hline & 2013 & \multirow{2}{*}{ bi14/13 } & 2014 & \multirow{2}{*}{ bi15/13 } & 2015 & \multirow{2}{*}{ bi16/13 } & 2016 & \multirow{2}{*}{ bi17/13 } & 2017 \\
\hline & $\mathbf{n}$ & & $\mathrm{n}$ & & $\mathbf{n}$ & & n & & $\mathbf{n}$ \\
\hline $\begin{array}{l}\text { Organisations educate employees } \\
\text { systematically }\end{array}$ & 98 & 1.020 & 100 & 0.000 & 98 & 1.041 & 102 & 1.102 & 108 \\
\hline $\begin{array}{l}\text { The organisation is focused on education } \\
\text { of all the categories of employees }\end{array}$ & 173 & 1.006 & 174 & 1.029 & 178 & 1.081 & 187 & 1.145 & 198 \\
\hline $\begin{array}{l}\text { Organisations assess effectiveness in } \\
\text { education }\end{array}$ & 84 & 1.012 & 85 & 1.060 & 89 & 1.167 & 98 & 1.179 & 99 \\
\hline$\Sigma$ & 355 & 1.011 & 359 & 1.003 & 356 & 1.090 & 387 & 1.141 & 405 \\
\hline
\end{tabular}

Source: own research. 
As Table 4 shows, the overall increase of focus on the education of employees in the interviewed organisations compared to the first year of the monitored period was recorded in each of the following analysed years. It can thus be concluded that the share of organisations focusing on the activities related to complex education of employees increased in the monitored period.

Table 5 shows the numbers of organisations according to the score of the examined attributes achieved in individual regions in year 2017.

Table 5

Focus of organisations on complex education of employees in regions according to NUTS

\begin{tabular}{|l|c|c|c|c|c|}
\hline Region - NUTS II. / & $\begin{array}{c}\text { Bratislava } \\
\text { Region }\end{array}$ & $\begin{array}{c}\text { Western } \\
\text { Slovakia }\end{array}$ & $\begin{array}{c}\text { Central } \\
\text { Slovakia }\end{array}$ & $\begin{array}{c}\text { Eastern } \\
\text { Slovakia }\end{array}$ & Slovakia \\
\hline Districts & BA & $\begin{array}{c}\text { TT, TN, } \\
\text { NR }\end{array}$ & BB, ZA & KE, PO & $\Sigma$ \\
\hline Focus of organisations on talent management & \multicolumn{5}{|c|}{5} \\
\hline Organisations educate employees systematically & 46 & 34 & 19 & 9 & 108 \\
\hline $\begin{array}{l}\text { The organisation is focused on education of all the } \\
\text { categories of employees }\end{array}$ & 68 & 55 & 42 & 33 & 198 \\
\hline Organisations assess effectiveness in education & 43 & 25 & 21 & 20 & 99 \\
\hline
\end{tabular}

Source: own research.

The major share of the companies executing the activities related to systematic education of employees was recorded in the region of Bratislava ( $n=46$ ), representing $42,59 \%$ of all the analysed organisations from this region. Likewise, the largest number of organisations from the region of Bratislava ( $\mathrm{n}=68$ ), representing $34,34 \%$, focused on the education of employees of all the categories of employees. Overall, $(n=198) 57.89 \%$ of Slovak organisations dealt with the activities related education of employees, but only $(n=99) 28.95 \%$ of them focused comprehensively on it.

The parametric Pearson's correlation test $(\mathrm{r})$ was used for the purpose of the statistical evaluation of individual correlations.

H1: The outcome of the Pearson's correlation test proves a statistically significant relationship between the region of operation of an organisation and the activities related to a systematic employee education process executed in it. The given variable correlates at the significance level sig. $=0.01$ with the value of the Pearson's correlation coefficient $r=0.312$. The required level of the significance value was achieved hence this hypothesis has not been rejected. A moderate relationship between the analysed variables can be confirmed.

H2: The outcome of the Pearson's correlation test proves a statistically significant relationship between the region of operation of an organisation and the focus of the organisation on the education of all the categories of employees. The given variable correlates at the significance level sig. $=0.01$ with the value of the Pearson's correlation coefficient $r=0.298$. The required level of the significance value was achieved hence this hypothesis has not been rejected. A moderate relationship between the analysed variables can be confirmed.

H3: The outcome of the Pearson's correlation test proves a statistically significant relationship between the region of operation of an organisation and the focus of the organisation on the implementation of the assessment of effectiveness in employee education. The given variable correlates at the significance level sig. $=0.01$ with the value of the Pearson's correlation coefficient $r=0.131$. The required level of the significance value was not achieved hence this hypothesis has been accepted. A weak relationship between the analysed variables can be confirmed. 
If human resource management is to effectively fulfil demanding roles associated with the formation of adequate potential in line with the objectives of companies, a functioning system of employee education and development, reacting to constantly changing environment, and leading to increased performance is necessary. Adaptation to global changes presupposes facing new challenges, gaining new knowledge and skills, and accepting new roles and responsibilities by both employees and employers. The key role will be predominantly played by personal development, which will be responsible for an ability of employees to succeed in these challenges. According to the "Digital Agenda 2020" study conducted in Germany, Austria and Switzerland in 2015, the greatest restraint in the currently ongoing digitalisation process is a lack of qualified employees and problems associated with their professional as well as further education (Rössler, 2015).

However, as a study conducted by the CRANET research network, which analysed more than 4,200 companies in 2014-2015 showed, organisations not always respect the necessity of systematic education of all employees and implemented different approaches to the creation and implementation of educational policies and strategies from random or unplanned (i.e. when necessary trainings are provided no sooner than after the need to gain the given knowledge or experience has arisen) to targeted approaches. A systemic approach to employee education was implemented by an average of $51.3 \%$ of EU organisations (Blštáková, 2018) and as our research showed by only $n=108$, representing $32 \%$, of Slovak organisations.

The effects of the seat of organisations on employee education was also analysed. Unfortunately, the results obtained by the research agreed with the results of a research conducted by the Business Alliance of Slovakia, which indicated that the highest education was achieved by citizens working in four districts of Bratislava, and the level of education decreased eastwards (Hajko et al., 2011). This situation may result in an even more significant increase of disparities between the economic performance of individual Slovak regions.

The assessment of effectiveness in employee education was also focused on, and such assessment was at the same time the starting point for the identification of further educational needs. The assessment should provide an answer to the question to what extent the set educational objectives have been fulfilled (Papula et al., 2018; Potkány, 2009). However, the results of the research documented insufficiencies in this area in Slovak organisations. The research study of the CRANET network indicated that effectiveness in educational processes was assessed by approximately $56 \%$ of Austrian and German companies. Despite the fact that the share of organisations dealing with the assessment of effectiveness in education increased in Slovakia from $\mathrm{n}=84(25 \%)$ to $\mathrm{n}=99(29 \%)$ in the monitored period, this is still unsatisfactory.

\section{CONCLUSIONS}

The article deals with changes in the focus of Slovak organisations on development of employees between 2013-2017 on the basis of partial indicators, such as individual activities related to education of employees, a finding whether the organisations provide employee education systematically, a finding whether organisations assess effectiveness in education, and the focus of the interviewed organisations on individual categories of employees being educated. The outcomes of this research are also presented in the context of the outcomes of researches conducted by authors, which provided a basis for evaluating the level of the data collected in Slovak organisations. With that in mind, the authors do not regard the present level as sufficient. However, the increasing trend clearly declared by the results of the research, has been evaluated positively. With reference to the fact that systematic work with employees is considered as key in ensuring competitiveness and added value in the future, we identify with authors such as Kachańáková et al. (2013) and Stachová et al. (2017), who declare that a functioning system of employee education and development, response to constant changes in environment and leading to increased 
performance has to be part of human resource management in order to fulfil demanding tasks associated with the formation of adequate potential in compliance with organisational objectives effectively.

\section{ACKNOWLEDGEMENT}

This work was supported by the Grant Agency VŠEMvs under Grant: Contribution of Selected Attributes of Managerial Work to Creation of Internal Environment Supporting Competitiveness of Companies [number 2/2016] and The Slovak Research and Development Agency under Grant: Transformation of the Paradigm of Business Management in Industrial Context [number APVV-17-0656].

\section{REFERENCES}

Arvanitis, S., Lookshin, B., Mohnen, P. et al. (2015). Inpact of External Knowledge Acquisition Strategies on Innovation: A comparative Study Based on Dutch and Swiss Panel Data. Review of Industrial Organization, 46(4), 359-382. doi: 10.1007/s11151-015-9450-7

Bartakova, P. G., Gubiniova, K, Brtkova, J, \& Hitka, M. (2017). Actual trends in the recruitment process at small and medium-sized enterprises with the use of social networking. Economic Annals-XXI, 164(3-4), 80-84.

Bersènaitè, J., \& Šaparnis, G. (2007). Assessment of Features, State and Success Factors of a Learning Organisation: Aspect of Staff Opinions. Social Research, 1(9), 20-27.

Bilan Y, Vasilyeva, T., Lyeonov, S., \& Bagmet, K. (2019). Institutional complementarity for social and Economic development. Business: theory and practice, 20, 103-115. https://doi.org/10.3846/btp.2019.10

Blštáková, J. (2018). Modely riadenia ludských zdrojov v ére priemyslu 4.0 [Habilitačná práca] Ekonomická Univerzita v Bratislave, Fakulta Podnikového Manažmentu, 145.

Brix, J. (2019). Innovation capacity building: An approach to maintaining balance between exploration and exploitation in organizational learning. The Learning Organization, 26(1), 12-26. https://doi.org/10.1108/TLO08-2018-0143

Chidambaram, R. (2014). To become a knowledge Economy. Curent Science, 106(7), 936-941.

Gavrea, C., Ilies, L., \& Stegerean, R. (2011). Determinants of organizational performance: the case of Romania. Management \& Marketing: Challenges for the Knowledge Society, 6(2), 285-300.

Hajko, J., Klátik, P., \& Tunega, M. (2011). Konkurencieschopné regióny, Bratislava: Devin printing house, 450.

Hitka, M., Lorincová, S., Ližbetinová, L., Bartáková, G. P., \& Merková, M. (2017). Cluster analysis used as the strategic advantage of human resource management in small and medium-sized enterprises in the woodprocessing industry. BioResources, 12(4), 7884-7897.

Hoole, C., \& Hotz, G. (2016). The Impact of a Total Reward System of Work Engagement. Journal of Industrial Psychology, 42(1), 1-14.

Hroník, F. (2007). Rozvoj a vzdelávani pracovníkủ. Praha: Grada Publishing.

Jankelova, N., Joniakova, Z., Blstakova, J., \& Nemethova, I. (2017). Readiness of human resource departments of agricultural enterprises for implementation of the new roles of human resource professionals. Agricultural Economics, 63(10), 461-470.

Joniaková, Z., Gálik, R., Blštáková, J., \& Tarišková, N. (2016). Riadenie ludských zdrojov. Bratislava: Wolters Kluwer.

Kachaňáková, A., Stachová, K., \& Stacho, Z. (2013). Riadenie ludských zdrojov v organizáciách pôsobiacich na Slovensku. Bratislava: Iura Edition.

Koisova, E., Habanik, J., Virglerova, Z., \& Rozsa, Z. (2017). Smes financing as an important factor of business environment in Slovak Republic Regions. Montenegrin Journal of Economics, 13(2), 129-140.

Korsakienè, R., Raišienè, A. G., \& Bužavaite, M. (2017). Work Engagement of Older Employees: do Employee and Work-Related Factors Matter? Economics \& Sociology, 10(4), 151-161. doi:10.14254/2071-789X.2017/10-4/12 
Kruss, G., McGrath, S., Petersen, I. H., \& Gastrow, M. (2015). Higher Education and Economic Development: The Importance of Building Technological Capabilities. International Journal of Educational Development, 43, $22-31$. doi: 10.1016/j.ijedudev.2015.04.011

Li, J., Brake, G., Champion, A., Fuller, T., Gabel, S., \& Hatcherbusch, L. (2009). Workplace Learning: The Roles of Knowledge Acccessibility and Management. Journal of Workplace Learning, 21(4), 347-364.

Marquardt, M. J. (1995). Building a Global Learning Organization: Lessons from the World's Top Corporations. Industry and Higher Education, 9(4), 217-226. https://doi.org/10.1177/095042229500900404

McDonell, A., Lavelle, J., \& Gunnigle, P. (2014). Human Resource Management in Multinational Enterprises: Evidence from a Late Industrializing Economy. Management International Review, 54(3), 361-380.

Nilson, S., \& Elström, P. E. (2012). Employability and Talent Management: Challenges for HRD Praktices. European Journal of Training and Development, 36(1), 26-45.

Örtenblad, A. (2001). On differences between organizational learning and learning organization. The Learning Organization, 8(3), 125-133. https://doi.org/10.1108/09696470110391211

Örtenblad, A. (2018). What does "learning organization" mean?. The Learning Organization, 25(3), 150-158. https://doi.org/10.1108/TLO-02-2018-0016

Papula, J., Kohnova, L., \& Papulova, Z. (2018). Impact of national culture on innovation activities of companies: A case of Germany, Austria, Switzerland and the Czech Republic. Economic Annals-XXI, 169(1-2), 26-30.

Pedler, M., \& Burgoyne, J. G. (2017). Is the learning organisation still alive?. The Learning Organization, 24(2), 119-126. https://doi.org/10.1108/TLO-12-2016-0087

Potkány, M. (2009). The methodology of creation of basic budgets types in commercial enterprise at the furniture sales. Acta Facultatis Xylologiae, 51(2), 105-119.

Rössler, M. (2015). Maschiene fordert Mensch heraus. Personalmagazin, 12, 18-21.

Rothwell, W. J., \& Williams, T. (2010). Effective Succession Planning: Ensuring Leadership Continuity and Building Talent from within. New York: Amacom.

Schlechter, A., Hung, A., \& Bussin, M. (2014). Undestanding Talent Atraction: The Influance of Financial Rewards Elements on Perceived Job Attractiveness: Original Research. SA Journal of Human Resource Management, 12(1) $1-13$.

Skrickienè, L., Čepuraitè, D., \& Štaras, K. (2018). Besimokanti organizacija šiuolaikinio viešojo valdymo kontekste [Learning organization in a context of contemporary public management]. Health sciences in Eastern Europe, 28(1), 57-66. https://doi.org/10.5200/sm-hs.2018.010

Stachová, K., Stacho, Z., \& Vicen, V. (2017). Efficient involvement of human resources in innovations through effective communication. Business: Theory and Practice, 18(1), 33-42. https://doi.org/10.3846/btp.2017.004

Susanty, A. I., \& Salwa, M. (2017). Knowledge Management Practices and Organizational Learning Have Positive Impacts on Organizational Performance of State-Owned Enterprises in Indonesia. Mediterranean Journal of Social Sciences, 8(3), 281-291. doi:10.5901/mjss.2017.v8n3p281

Tansley, C., Hafermalz, E., \& Dery, K. (2016). Talent Development Gamification in Talent Selection Assessment Centres. European Journal of Training and Development, 40(7), 490-512. https://doi.org/10.1108/EJTD-03-20160017

Vázquez, J.L., Lanero, A., \& Licandro, O. (2013). Corporate Social Responsibility and Higher Education: Uruguay University Students' Perceptions. Economics \& Sociology, 6(2), 145-157. DOI: 10.14254/2071-789X.2013/6$2 / 13$

Vnoučková, L. (2013). Employee Learning and Development in Organizations. Journal of Efficiency and Responsibility in Education and Science, 6(3), 179-189. DOI: 10.7160/eriesj.2013.060305

Wang, C.L., Ahmed, K. P. (2003). Organisational learning: a critical review, The Learning Organization, 10(1), 8-17. https://doi.org/10.1108/09696470310457469 